\title{
Self-perceived Age and Attitudes Toward Marketing of Older Consumers in China
}

\author{
Bin Ying $\cdot$ Rui Yao
}

Published online: 27 April 2010

(C) The Author(s) 2010. This article is published with open access at Springerlink.com

\begin{abstract}
Understanding consumer psychological characteristics and their impact on consumer behavior is an important foundation for business marketing strategies. Self-perceived age has a great impact on older consumers' behavior. This article defines the gray market in China, investigates the factors that affect the differences between older consumers' self-perceived age and life age, and analyzes the influence of self-perceived age on older Chinese consumers' behavior. In this study, 1,120 older consumers were randomly selected from six cities in China. Findings show that over half of the respondents feel younger than their actual life age. Related marketing strategies are discussed.
\end{abstract}

Keywords Consumer behavior - Life age ·

Older consumer $\cdot$ Physiological age $\cdot$ Self-perceived age

\section{Self-perceived Age of Older Chinese Consumers}

Aging population is an inevitable result of the development of human society. At present, approximately one-third of the countries and regions in the world have already become old-age societies. It is estimated that over $90 \%$ of the countries and regions in the world will develop into old-age

\footnotetext{
B. Ying

Business Administration School, Zhongnan University of Economics and Law, Wuhan 430060, Hubei Province, People's Republic of China

e-mail: yingbincn@yahoo.com

R. Yao $(\bowtie)$

Personal Financial Planning Department, University of Missouri, 239B Stanley Hall, Columbia, MO 65211, USA

e-mail: yaor@missouri.edu
}

societies by 2050 (United Nations 2002). China turned into an old-age society in 1999. Ever since then, the elderly population in China has grown rapidly at an annual rate of $3.2 \%$, which is almost three times the overall population growth rate (Xie et al. 2007). It is estimated that by 2050, China will grow to be a highly aging country with around $31 \%$ of its population being older people (Abdel-Ghany 2008). A huge gray market already exists in China. Understanding older consumers' psychology and their behavior have significant implications for marketing strategies, and, therefore, have become important tasks for researchers and professionals in the marketing field.

Consumer psychology and consumer behavior are two basic research topics in the current marketing field. They are also the important foundation for business marketing strategies. Self-perceived age, as opposed to physiological age and life age, has a greater influence on older consumers' behavior. In China, it is generally believed that the self-perceived age of senior citizens is younger than their physiological age and their life age. However, empirical research is needed to study the actual relationship between these ages and find whether self-perceived age could affect older Chinese consumers' behavior and the effectiveness of business marketing strategies.

Age and Its Measures

Age is a physical condition and, at the same time, a psychological condition (Sherman and Schiffman 1991). There is no generally accepted and explicit term to describe and measure the psychological condition. Kastenbaum et al. (1972) suggested four dimensions of this psychological condition: the age a person feels, the age a person thinks he/she looks, the age a person perceives him/herself to act, and the age a person perceives to be reflective of his/her 
interests. Many similar concepts and terms have been used in previous literature. Barak and Schiffman (1981) and Underhill and Cadwell (1983) defined cognitive age as the arithmetic average of the above four dimensions of ages. Sherman and Schiffman (1991) stated that self-perceived age indicates how old an individual feels he/she is. Due to the complicated computation of cognitive age, most research adopted the term self-perceived age, which is, therefore, the term used in this study.

Physiological age and life age measure people's physical condition. It is important to note that these terms are two different concepts. Life age is the measure of one's natural age, which is the time that has been elapsed since an individual was born; while physiological age is determined based on an individual's physical well-being that is reflected by the function of such individual's cells and organs. Life age does not necessary correctly reflect an individual's physical function, psychological status, or social ability due to individual differences in genes, environment, illness, nutrition, and sports activities. Generally, individuals know their life age but have difficulty understand their physiological age, which requires technology and trained professionals to measure accurately. Most studies employed the life age in the analyzing consumer behavior due to the simplicity to obtain (Borra and Palma 2009; Kim and Kim 2010). In this study, respondents were asked to provide their life age and report their self-perceived age.

\section{Gap Between Self-perceived Age and Life Age}

Past research has consistently found that adults tend to feel younger than their life age (Barak and Stern 1986; Goldsmith and Heiens 1992; Montepare and Zebrowitz 1998; Westerhof et al. 2003). Research demonstrates that, in most situations, people older than age 50 tend to have a selfperceived age that is 10 to 15 years younger than their life age (Tréguer 2002). The reason of this discrepancy is that people feel more comfortable this way and can function better with their current skills, physical strength and mental ability. In 1999, a French IFOP research discovered that $45 \%$ of older people of age 60 and above felt that they were younger than 50 years old (Tréguer 2002). The majority of older people had a self-perceived age that was about 10 years younger than their life age. Some well-educated older people even felt themselves to be 30 years younger than their life age (Tréguer 2002). In 2000, Shiseido, a famous Japanese cosmetics group, studied the difference between the life age and the perceived age of older women of age 50 and above. They found that on average, those between 60 and 64 year old women perceived themselves to be around 52.7 years old, a 9.1 years difference between their life age and their perceived age. Their research results also showed that women between 65 and 70 year old felt themselves to be about 57.9 years old, an 8.9 years difference between their life age and their perceived age (Tréguer 2002).

In typical western culture, old age is viewed negatively as it has been linked to the decline of social status (Fry 1996). On the contrary, in Chinese culture, old age is traditionally associated with being wise and respectful. Nonetheless, Chinese people still prefer looking younger than they actually are. Older Chinese people always say, "I feel younger and younger." This implies that their selfperceived age is younger than their life age. In Chinese culture, feeling young is the key to a healthy and positive attitude toward life and longevity (Xu 2006). Results from a recent national survey on older persons showed that the self-perceived age of older people has declined (Gui 2006). In the survey, the average age of the respondents was 60.5 and their self-perceived ages were between 29 and 30 . What factors affected such a big difference between selfperceived age and life age is worth exploring, given its potential benefits to researchers and professionals in the marketing field.

There exist two major ways to define the gray market: (1) the market that are made of people of life age 50 and above; (2) the market that are made of people of life age 55 and above. The majority of the previous research adopts the first definition (e.g. Beck 1996; Burt and Gabbot 1995; Kang and Ridgway 1996; Mazur 1993; Mitchell 1996; Semon 1995; Trappey and Lai 1997; Weaver 1996), which is, therefore, the definition used in this research.

\section{Benefits of Understanding Self-perceived Age}

Understanding factors that affect having a younger selfperceived age than life age has great potential to impact marketing strategies targeted to the enormous gray market in China.

\section{Better Understand Consumer Behavior of the Elderly}

Perception of the concept "old age" may change as people age. Many people of age 60 and above would not want to admit that they have joined the "old age" club. Many of them feel 10 years younger than they actually are (Brown 1986). Therefore, it is important to understand that investigation of actual life age may not be the best way to understand consumption demand.

Past research showed that older consumers are often consistent with younger consumers in terms of their perceptions and behaviors related to age (Barak and Schiffman 1981; Underhill and Cadwell 1983). The phenomenon of having a self-perceived age younger than one's life age exists in both male and female consumer groups (Barak and Rahtz 1989). Sherman et al. (1988) concluded that 
generally, those who have a younger self-perceived age than life age are more satisfied with life. Self-perceived age is also closely related to consumer behavior. Older women who feel younger are usually more confident and more interested in fashion. They are more work-oriented instead of family-oriented and are more likely to participate in activities related to entertainment and culture. These women tend to care more about their personal image, which affects both their attitude toward clothing and their apparel purchasing behavior (Wilkes 1992). In order to understand older consumers, researchers must thoroughly understand factors that influence their self-perceived age and the relationship between their self-perceived age and their value system, lifestyle and attitudes toward marketing activities.

\section{Build More Accurate Marketing Positions}

It has become more and more important for marketing professionals to understand older consumers' self-perceived age. Many senior consumers do not wish to be described as the disadvantaged group who cannot effectively take care of themselves or make rational consumption decisions (Mason and Smith 1977). In the literature, the older-consumer market (formed by consumers of 50 and above) has been described as being complex and unpredictable (Anon 1992; Mitchell 1983). These negative impressions have long hindered the development of marketing in the older consumer market. Recently, more and more older consumers feel younger than they actually are and consider the expression "elderly" to be an inappropriate description of themselves. In response to this trend, some marketing professionals have started to revisit their understanding of the gray market (Andrews and Mckeever 1990; Anon 1991; Mazur 1993).

Those products that were often targeted to "senior consumers" in the past are being rejected by older consumers now. Even soft expressions such as "the golden age" and "the mature market" have all encountered criticism from older consumers (Mitchell 1996). Ying and Yao (2006) found that older consumers had similar consumption needs as younger adults. Therefore, treating those consumers with a younger self-perceived age the same way as younger consumers may be more beneficial for businesses. It was discovered in some literature that older consumers do not like to be described as being "old" and "slow" in advertisements. This does not mean that businesses should use young people to be the spokesman in all advertisements. On the contrary, older consumers welcome advertisements that feature "healthy" and "vigorous" consumers of older ages (Carrigan and Szmigin 1998). Marketing professionals must thoroughly understand older consumers before they can effectively select a target market (Goodhead 1991; Miller 1991).
Factors that Influence Self-perceived Age

In previous research, self-perceived age has been found to be positively correlated with life age (Barak and Rahtz 1989; Wilkes 1992) and negatively related to being married (Barak and Rahtz 1989; Wilkes 1992) and having higher income (Barak and Rahtz 1989; Wilkes 1992). Westerhof et al. (2003) concluded that older adults tended to have a larger discrepancy between their self-perceived age and their life age than younger individuals (Barak and Stern 1986; Goldsmith and Heiens 1992; Montepare and Lachman 1989). Past research was not consistent in their findings on the effect of gender on self-perceived age. Most studies found that males and females did not differ significantly in their self-perceived age (Barak and Rahtz 1989; Henderson et al. 1995). However, Montepare and Lachman (1989) found that females tend to have a younger self-perceived age than males. The inconsistency also exists in the effect of work force participation on selfperceived age. Barak and Rahtz (1989) found that not being in the work force had a positive effect on self-perceived age; while Wilkes (1992) found that the relationship was not statistically significant.

\section{The Present Study}

The majority of past research on self-perceived age in China was on the general public. This study is the first empirical research in China that focuses on self-perceived age of older consumers. Traditionally, it was believed that older Chinese consumers were conservative in their value system and lifestyle. Recently, some research found that some older consumers in China started to be more open than before. This study investigates the above two characteristics of older consumers and their relationship with self-perceived age. This study also contributes to the literature by examining the differences in self-perceived age and life age, factors that impact the self-perceived age of older Chinese consumers, and implications for marketing professionals on expanding the gray market in China.

\section{Methodology}

In order to better understand the gray market in China and help businesses to find a more reasonable position in this particular market, this study investigates the self-perceived age of older Chinese consumers. Factors related to older consumers' likelihood of having a younger self-perceived age are identified and implications to businesses regarding marketing strategies for older Chinese consumers are discussed. 


\section{Questionnaire Design}

There are four major sections in the questionnaire: older consumers' self-perceived age and life age, older consumers' value system and lifestyle, older consumers' attitude toward marketing activities, and demographic and economic background of older consumers.

\section{Older Consumers' Self-perceived Age and Life Age}

Following the self-perceived age definition by Sherman and Schiffman (1991), i.e. the age that an individual feels he/she is, the question related to self-perceived age in the questionnaire was "You stated that your life age was 50 . Please indicate, which one of the following age categories best describes the age that you feel you are of? Below 30; 30 to $39 ; 40$ to $49 ; 50$ to $59 ; 60$ to $69 ; 70$ and above; or don't know."

\section{Older Consumers' Value System and Lifestyle}

Due to enormous historical, social, and cultural differences, Chinese consumers' value system and lifestyle are significantly different from that of western consumers. Therefore, western value system and lifestyle cannot be adopted to study Chinese consumers. Harmony and balance between nature, human, and society were the traditional values ( $\mathrm{Li} \mathrm{1998).} \mathrm{Currently,} \mathrm{China} \mathrm{is} \mathrm{experiencing} \mathrm{a} \mathrm{tran-}$ sition period when diversified social values coexist such as those that are traditional and modern, advanced and underdeveloped, eastern and western ( $\mathrm{Liu}$ and $\mathrm{Li}$ 1994). Based on previous literature, the authors propose two trends in older Chinese consumers value system: first, the traditional and conservative value system, mainly including diligent, thrift, professional, impartial, humble, obedient, and restraining values; second, the modern and open value system, mainly including individualistic, multiplex, competitive, socially responsible, hard-working, successful, welcoming changes, fashionable, and valuing life more than work values. The following are measures of the two value systems designed by the authors after examining and summarizing previous research. A pilot study and tests was conducted to examine the validity and reliability of the instruments. The reliability estimates of the individual items in the value and lifestyle scale were above 0.70, indicating acceptable reliability (Nunnally 1978). The Cronbach's alpha for the scale was 0.82 , an indication of a good reliability of the scale. To conduct the concurrent validity test, the correlation between each of the 28 items in the value system and lifestyle scale with similar measures used in previous research was tested. The correlation coefficients were all above 0.50 , therefore, these items are considered valid.
The traditional and conservative value system and lifestyle items are: (1) I believe we should be diligent and thrift; (2) The boss is always right; (3) When they grow up, children should financially support their parents; (4) I find it unbelievable to spend a lot of money on entertainment; (5) I usually spend lots of money on my spouse and child but seldom buy anything for myself; (6) I seldom spend money on myself but save money for my offspring; (7) I care what others think of me; (8) I hope to be accepted by the society; (9) I believe we should work hard whether we like the job or not; 10) I believe we should treat others well; (11) I like to live in an extended family; 12) I cannot stand things that I cannot accept; (13) I do not praise myself in front of others; (14) I believe we should not spend money without a plan and should save money for emergencies.

The modern and open value system and lifestyle items are: (1) I like to try new things; (2) I follow the latest trend and fashion; (3) I am more capable than most others; 4) I believe enjoying life is more important than working; (5) I long for excitement; 6) I will not buy anything that are not useful to me even if they are very cheap; (7) I like to be the leader in a team; (8) I like a life that is full of changes; (9) I like to do things the way I like; (10) I like freedom and independency; (11) I will buy things I like even if I have to borrow money to buy them; (12) I did not have money when I was young; now that I have some money, I should spend it when I need to; (13) I am not as young as before so I believe I should enjoy life when I can; (14) I am more fashionable than more others.

The traditional and modern value systems and lifestyles only reflect the changes in consumer's value system and lifestyle due to the changes in the society. These changes are not treated as being positive or negative in this study. "Traditional" does not mean out-dated or bad and, similarly, "modern" does not mean appropriate or good.

\section{Older Consumers' Attitude Toward Marketing Activities}

In order to examine different older consumers' attitude toward marketing activities, a measure with five dimensions (designed by Moschis 1992) was used. These five dimensions include older consumer's attitude toward: (1) product strategies; (2) product satisfaction; (3) sales promotions; (4) pricing strategies; and (5) channel strategies. Respondents were asked to rate on a 5-point scale, with 1 being totally disagree and 5 being totally agree.

\section{Demographic and Economic Characteristics of Older Consumers}

These characteristics include (1) gender; (2) age; (3) marriage status; (4) employment status; (5) education level; (6) income level; and (7) household size. 
Sample Selection

A total of six cities were selected to draw sample from. These cities are Beijing, Shanghai, Wuhan, Shenzhen, Kunming, and Jiangmen. Beijing is located in the north of China, which is the political center. Shanghai is located in the east of China, which is the economic center. Wuhan is located in the center of China, which is an in-land city with a long history. Shenzhen and Jiangmen are relatively newly established cities that are located in the south of China, which are along the coast and close to Hong Kong and Macao. Kunming is located in the west of China, which is comparatively underdeveloped. Jiangmen is a small city, Kunming is a middle-sized city, and others are large cities. These six cities represent the gray market in China and, at the same time, have differences among themselves.

Questionnaires were handed out to the respondents to complete. Initial instructions were given to respondents on how to complete the questionnaire. Survey interviewers assisted participants by reading the questions to those who could not mark their answers due to health problems or educational barriers. Participants were required to complete the survey on-site and hand it to the interviewer upon completion.

Survey respondents were randomly selected in each city. In Wuhan and Jiangmen, 240 respondents were selected and 160 respondents were selected in all other cities. In each city, the number of respondents in each district was determined according to the size of local population. For example, Wuhan has seven districts. Five to seven sample collection blocks in each district was selected according to the size of local population. The sample was drawn from a total number of 40 blocks with six samples selected from each block. Therefore, the total sample size from Wuhan was 240. The sample selection blocks were residential buildings, elderly homes, universities for older people and parks. Contact information of older persons in residential buildings, elderly homes and universities was obtained from their administration offices. Information slips were mixed and randomly drawn. Respondents in the parks were irregularly stopped until the number of respondents reached the desired level. Each selected older person had to be 50 years or older and had to have lived in the city for three consecutive years or more, otherwise another respondent would be randomly chosen to replace the person who did not meet the above criteria.

The survey was conducted between October and November 2004. Survey interviewers were sophomore and junior marketing students in the Business School at Zhongnan University of Economics and Law. They completed a total of 3-h's training on survey interviewing before they conducted the survey.

Before each interview, the interviewer was required to introduce him/herself and let the respondent know that this was a non-business related academic research and assure them of the confidentiality of the study. After receiving the completed questionnaire, the interviewer was required to quickly scan the answers and ask the respondent to answer the unanswered questions, if any. Each survey took between 10 to $25 \mathrm{~min}$ to complete.

From the past experience of data collection in China, respondents are more likely to respond to questions that provide categories of choices than open-ended questions. Therefore, all variables in the study were categorical. The total number of questionnaires distributed for the purpose of this study was 1,120 . A total of 916 valid questionnaires were received, making the response rate of $81.79 \%$.

\section{Method of Analysis}

Cross-tabulations were conducted to observe the relationships between self-perceived age and life age, self-perceived age and lifestyle, and self-perceived age and attitude toward marketing activities. Two-sample $t$-tests were conducted to investigate the mean differences in attitude toward marketing activities for those who perceived themselves to be younger than 50 and those with a selfperceived age of 50 or older. A logistic regression was performed to identify factors that influence the likelihood of having a younger self-perceived age.

\section{Results}

\section{Sample Characteristics}

Among the 916 older respondents who were 50 years or older, most respondents $(51.42 \%)$ were between 50 and 59 years old; $33.07 \%$ were in their $60 \mathrm{~s}$; and $15.50 \%$ were 70 years or older (Table 1). Most respondents were males (58.41\%), married $(87.34 \%)$, and not working $(58.30 \%)$. About two-fifths $(39.41 \%)$ of the total respondents had a less than high school education; $31.00 \%$ completed high school or its equivalent level of education; $13.32 \%$ had some college; $14.30 \%$ had a Bachelor's degree or obtained higher education. The median household size was three. About one-third of the respondents lived in a one- or twoperson household; $47.38 \%$ of them lived in a household with three or four people; $18.45 \%$ lived in larger households with five or more members. As shown in Table 1, median respondent individual income was between $¥ 800$ and $¥ 1,499$ per month and median monthly household income was between $¥ 2,000$ and $¥ 3,999$.

Self-perceived Age and Life Age

The results showed that over one-third of the respondents $(34.50 \%)$ had a self-perceived age younger than 50 years; 
Table 1 Respondent characteristics

\begin{tabular}{|c|c|c|}
\hline Characteristic & No. of respondent & $\%$ \\
\hline \multicolumn{3}{|l|}{ Self-perceived age } \\
\hline$<40$ & 118 & 12.88 \\
\hline $40-49$ & 198 & 21.62 \\
\hline $50-59$ & 307 & 33.52 \\
\hline $60-69$ & 196 & 21.4 \\
\hline$\geq 70$ & 69 & 7.53 \\
\hline Don't know & 28 & 3.06 \\
\hline \multicolumn{3}{|l|}{ Life age } \\
\hline $50-59$ & 471 & 51.42 \\
\hline $60-69$ & 303 & 33.07 \\
\hline$\geq 70$ & 142 & 15.5 \\
\hline \multicolumn{3}{|l|}{ Gender } \\
\hline Male & 535 & 58.41 \\
\hline Female & 381 & 41.59 \\
\hline \multicolumn{3}{|l|}{ Marital status } \\
\hline Married & 800 & 87.34 \\
\hline Unmarried & 116 & 12.66 \\
\hline \multicolumn{3}{|l|}{ Employment status } \\
\hline Working & 382 & 41.7 \\
\hline Not working & 534 & 58.3 \\
\hline \multicolumn{3}{|l|}{ Education } \\
\hline Less than high school & 361 & 39.41 \\
\hline High school & 284 & 31 \\
\hline Some college & 122 & 13.32 \\
\hline Bachelor's degree or above & 149 & 16.27 \\
\hline \multicolumn{3}{|l|}{ Respondent monthly income } \\
\hline Less than $¥ 800$ & 273 & 29.8 \\
\hline$¥ 800-1,499$ & 277 & 30.24 \\
\hline$¥ 1,500-2,999$ & 240 & 26.2 \\
\hline$¥ 3,000$ or above & 126 & 13.75 \\
\hline \multicolumn{3}{|l|}{ Household monthly income } \\
\hline Less than $¥ 2,000$ & 296 & 32.32 \\
\hline$¥ 2,000-3,999$ & 288 & 31.45 \\
\hline$¥ 4,000-5,999$ & 168 & 18.34 \\
\hline$¥ 6,000$ or above & 164 & 17.9 \\
\hline \multicolumn{3}{|l|}{ Household size } \\
\hline 1 & 53 & 5.79 \\
\hline 2 & 260 & 28.38 \\
\hline 3 & 276 & 30.13 \\
\hline 4 & 158 & 17.25 \\
\hline$\geq 5$ & 169 & 18.45 \\
\hline
\end{tabular}

Note: Total sample size $=916$

and another one-third (33.52\%) perceived themselves to be in their 50s. Table 2 showed that the majority of respondents (51.79\%) had a younger self-perceived age than their life age, which is consistent with previous research such as Brown (1986), Barak and Rahtz (1989), and Tréguer
Table 2 Self-perceived age and life age of older Chinese consumers

\begin{tabular}{|c|c|c|c|c|c|c|}
\hline \multirow[t]{3}{*}{ Self-perceived age } & \multicolumn{6}{|c|}{ Life age } \\
\hline & \multicolumn{2}{|c|}{$50-59$} & \multicolumn{2}{|c|}{$60-69$} & \multicolumn{2}{|c|}{$\geq 70$} \\
\hline & No. & $\%$ & No. & $\%$ & No. & $\%$ \\
\hline$<30$ & 15 & 1.69 & 4 & 0.45 & 4 & 0.45 \\
\hline $30-39$ & 72 & 8.11 & 14 & 1.57 & 9 & 1.01 \\
\hline $40-49$ & 158 & 17.79 & 36 & 4.05 & 4 & .45 \\
\hline $50-59$ & 201 & 22.63 & 88 & 9.91 & 18 & 2.03 \\
\hline $60-69$ & 10 & 1.12 & 148 & 16.67 & 38 & 4.28 \\
\hline$\geq 70$ & 0 & 0.00 & 6 & 0.68 & 63 & 7.10 \\
\hline
\end{tabular}

Note: Total sample size $=888$ without those who responded "Don't know" to the self-perceived age question

(2002). The results indicated a large gap between the selfperceived age and the life age of older Chinese consumers. Of the respondents perceived themselves to be younger than their life age, about one-fifth $(19.81 \%)$ perceived themselves to be at least 10 years younger than their life age (Table 2); $5.62 \%$ of them had a self-perceived age that was at least 20 years younger than their life age; some even perceived themselves to be at least 30 years younger than they actually were. It is also worth noticing that $16(1.80 \%)$ perceived themselves to be older than they actually were and $28(3.06 \%)$ chose the answer "Don't know."

\section{Predictors of a Younger Self-perceived Age}

Gender, employment status, household monthly income, and respondent monthly income had a significant effect on the likelihood of perceiving an age that is younger than own life age (Table 3). Controlling for other factors, males were only $71.74 \%$ as likely as females to have a younger self-perceived age than their actual life age. Respondents who were employed at the time of the interview were 1.42 times as likely as their otherwise similar non-working counterparts to have a younger self-perceived age. Household and individual monthly income level also had a significant positive impact on the self-perceived age of older Chinese consumers.

\section{Self-perceived Age and Older Consumers' Value System and Attitudes}

Table 4 showed that older consumers who perceived themselves to be under 50 years old are more open-minded regarding their values and lifestyles. Compared to older consumers with a self-perceived age older than 50, those with a younger self-perceived age were 1.42 times more likely to be open-minded (24.48 and $34.82 \%$, respectively). Among those with a self-perceived age over 50 years, $75.52 \%$ showed a conservative value system and lifestyle, 
Table 3 Logistic analysis of the likelihood of a younger selfperceived age

Note: $* p<0.05, * * p<0.01$

\begin{tabular}{llll}
\hline Parameter & Coefficient & Standard error & Odds ratio \\
\hline Intercept & -0.4317 & 0.3415 & \\
Age 50-59 & 0.0010 & 0.1759 & 1.0010 \\
Age $\geq 70$ & 0.2761 & 0.2160 & 1.3180 \\
Male & $-0.3321^{*}$ & 0.1468 & 0.7174 \\
Married & -0.0889 & 0.2201 & 0.9149 \\
Employed & $0.3536^{*}$ & 0.1704 & 1.4242 \\
Less than high school & -0.1099 & 0.1773 & 0.8959 \\
Some college & -0.1115 & 0.2301 & 0.8945 \\
Bachelor's degree or higher & -0.3082 & 0.2433 & 0.7348 \\
Household monthly income & $0.0430^{*}$ & 0.0199 & 1.0439 \\
Respondent monthly income & $0.1050^{* *}$ & 0.0381 & 1.1107 \\
Household size & -0.0759 & 0.0626 & 0.9269 \\
Concordance & $62.9 \%$ & & \\
Chi-square test of the likelihood ratio & $47.5081<0.0001$ & & \\
\hline
\end{tabular}

Table 4 Value system and lifestyle of older consumers

\begin{tabular}{|c|c|c|c|c|}
\hline \multirow[t]{2}{*}{ Value system } & \multicolumn{2}{|c|}{ Self-perceived age $\leq 50$} & \multicolumn{2}{|c|}{ Self-perceived age $>50$} \\
\hline & $\begin{array}{l}\text { No. of } \\
\text { respondents }\end{array}$ & $\%$ & $\begin{array}{l}\text { No. of } \\
\text { respondents }\end{array}$ & $\%$ \\
\hline Conservative & 206 & 65.19 & 432 & 75.52 \\
\hline Open & 110 & 34.82 & 140 & 24.48 \\
\hline Total & 316 & 100 & 572 & 100 \\
\hline
\end{tabular}

while the percentage of those with a self-perceived age younger than 50 was $65.19 \%$.

Table 5 presents the mean differences in attitude toward marketing activities for those with a self-perceived age younger than 50 and 50 or above. Compared to consumers with an older self-perceived age, those who perceived themselves to be under 50 years old were more likely to try new products, buy name brand products, be attracted by sales strategies such as advertisements, discounts, and window displays. They tend to be more likely to welcome help from sales persons, accept the bank card payment method, and be willing to spend more for quality and convenience. These two groups did not show a big difference in their attitude toward product satisfaction.

\section{Self-perceived Age and Positioning the Gray Market}

Previous research found that older consumers, especially those with a younger self-perceived age, do not like to be described as being old and slow. Table 6 showed that most older consumers do not like to name the products that were targeted to them to be "old age products". They also do not like other names such as "mature age products", "silverhair products" and "silver products".

\section{Discussion and Implications}

The negative old, slow and stubborn image of older consumers has long hindered the development of the gray market. It was found in the study that over one-third of older Chinese consumers perceived themselves to be younger than 50 years. Over half of the respondents felt younger than their actual life age. Only very few had a selfperceived age that was older than their life age. Therefore, marketing professionals with the old belief that "the old man decays" are challenged to re-evaluate and reposition the gray market. Due to the social development and technology advancement, people live longer today. The "midlife" and "middle-age" concepts may be shifted: they were used to describe those in their 30s and now 50s may be the new 30s. Moreover, there have been changes in the labor market. People work longer now than before and the "full retirement age" defined by Social Security is delayed to 67 from the previous 65 in the U.S. Marketing professionals should recognize the changes in the labor market and the shift in age perceptions and develop appropriate products and relevant marketing strategies to better target the older consumers group.

As shown by the results of this study, some older consumers maintain a younger self-perceived age than their life age. Self-perceived age, compared to life age, has a more profound impact on consumer behavior. This study identified factors that have an effect on perceiving a younger age than life age. Future research should make a step further to investigate the size of the gap between selfperceived age and life age and better help marketing professionals to target the appropriate group of older consumers.

There is no generally accepted product name for older consumers (Table 6). In order to prevent negative reaction 
Table 5 Self-perceived age and attitude toward marketing activities

\begin{tabular}{|c|c|c|c|}
\hline Attitude toward marketing activities & $\leq 50$ & $>50$ & $p$-Value \\
\hline \multicolumn{4}{|l|}{ Attitude toward product strategies } \\
\hline 1. I like to try new products & 3.09 & 2.73 & \multirow[t]{2}{*}{$* * *$} \\
\hline 2. I will always use the brands that I like & 3.44 & 3.32 & \\
\hline 3. I like to purchase name brands & 2.87 & 2.52 & \multirow[t]{3}{*}{$* * *$} \\
\hline 4. I seldom pay attention to product quality guarantee & 2.71 & 2.65 & \\
\hline 5. I won't buy new products unless people that I know have confirmed that they are OK. & 3.43 & 3.39 & \\
\hline \multicolumn{4}{|l|}{ Attitude toward product satisfaction } \\
\hline 6. If I am not satisfied with a product, I usually will inform relatives and friends. & 3.86 & 3.89 & \\
\hline 7. If I like a product, I usually will recommend it to relatives and friends. & 3.84 & 3.77 & \\
\hline \multicolumn{4}{|l|}{ Attitude toward sales strategies } \\
\hline 8. I do not trust advertisements. & 3.40 & 3.51 & \\
\hline 9. I have the experience of buying a product because I liked its advertisement. & 2.74 & 2.45 & \multirow[t]{2}{*}{$* *$} \\
\hline 10. Before I try a free sample, I usually would not buy new food products. & 3.19 & 3.10 & \\
\hline 11. I often shop in a store because I was attracted by its window display. & 2.76 & 2.23 & $* * *$ \\
\hline 12. Discount activities often induce me to buy things I do not plan to buy. & 2.74 & 2.34 & \multirow[t]{2}{*}{$* * *$} \\
\hline $\begin{array}{l}\text { 13. I dislike coupons distributed by stores because they are troublesome. } \\
\text { They are usually the results of increased prices. }\end{array}$ & 3.50 & 3.43 & \\
\hline 14. I use coupons whenever I can. & 3.34 & 3.11 & $*$ \\
\hline 15. Businesses won't treat me like a friend; they only want my money. & 3.66 & 3.73 & \\
\hline \multicolumn{4}{|l|}{ Attitude toward pricing strategies } \\
\hline 16. I am willing to spend more money for higher quality. & 3.74 & 3.18 & $* * *$ \\
\hline \multicolumn{4}{|l|}{ Attitude toward channel strategies } \\
\hline 17. I often visit stores and malls. & 2.81 & 2.80 & \\
\hline 18. I like to shop where I usually shop. & 3.58 & 3.59 & \\
\hline 19. I like to shop in bigger stores rather than smaller ones. & 3.45 & 3.29 & \\
\hline 20. I don't mind the price to be a little higher if the store is close by where I live. & 3.24 & 2.85 & $* * *$ \\
\hline 21. I frequently buy things through the mail order. & 2.16 & 1.79 & $* * *$ \\
\hline 22. I like to be helped by sales persons when I shop. & 2.91 & 2.56 & $* * *$ \\
\hline 23. I wish all stores had sales consultants. & 3.13 & 2.81 & $* * *$ \\
\hline 24. I wish there were more checkouts in all stores that would accept credit cards. & 3.24 & 2.74 & $* * *$ \\
\hline 25. When shopping, I am more likely to pay cash than use bank cards. & 3.45 & 3.68 & $* *$ \\
\hline 26. I like to interact with sales people, service people and other consumers. & 3.01 & 2.72 & $* * *$ \\
\hline 27. I had bad experiences with sales professionals and service people. & 2.89 & 2.61 & $* *$ \\
\hline
\end{tabular}

Note: $* p<0.05, * * p<0.01, * * * p<0.001$

Table 6 Product names that are accepted by older Chinese consumers

\begin{tabular}{lcr}
\hline Product name & No. of respondents & $\%$ \\
\hline Mid-to-old-age products & 334 & 36.46 \\
Old-age products & 112 & 12.23 \\
Mature products & 78 & 8.52 \\
Silver products & 78 & 8.52 \\
Silver-hair products & 17 & 1.86 \\
None of the above & 297 & 32.42 \\
\hline
\end{tabular}

Note: The question was, "If a business is developing a product for you, which of the following names would you prefer to name the products?" of older consumers, businesses should avoid using a particular phrase for products that indicate "old age". Instead, they should use words that give older consumers the image of being "healthy, energetic and young inside". Table 6 well demonstrated the fact that older consumers do not like any of the product names that indicate their old age. Because many older consumers do not wish to be considered old, in advertisement and sales promotions that target this group of people, businesses should avoid using product names that signify the age of older consumers. Older consumers with a younger self-perceived age than life age have a value system and lifestyle that is more open than those with a same or older self-perceived age. Therefore, 
consumers who feel younger are more likely to accept new things and behave more like middle-aged consumers. Since the majority of older consumers perceive themselves to be younger than they actually are, businesses should not treat them substantially differently from middle-aged consumers in their marketing and sales strategies. When designing marketing strategies for the gray market, businesses should try to meet the special consumption needs of older consumers by developing new products and services that satisfy older consumers' need to feel young.

Those older consumers who have a younger self-perceived age have demonstrated different characteristics from traditional older consumers in their consumption behavior. These consumers are more willing to accept new products, less sensitive to prices, and more willing to spend money on themselves. Therefore, these consumers are more important to businesses in that they have more potential to become loyal customers and bring more profit to businesses. They can also have impact on other older consumers, which can result in more sales for businesses.

This study did not include consumers in rural areas, where the majority of Chinese population live. The potential of the rural gray market development is huge. Future research should study the impact of self-perceived age of rural older consumers on their consumption behavior.

Open Access This article is distributed under the terms of the Creative Commons Attribution Noncommercial License which permits any noncommercial use, distribution, and reproduction in any medium, provided the original author(s) and source are credited.

\section{References}

Abdel-Ghany, M. (2008). Problematic progress in Asia: Growing older and apart. Journal of Family and Economic Issues, 29, 549-569.

Andrews, K., \& Mckeever E. (1990). Grey is the future colour of money. Leisure Business, April, 33-34.

Anonymous. (1991). Get set for old age. Leisure Manager, 9(11), 2730.

Anonymous. (1992). The rich autumn of a consumer's life. Economist, 324(7775), 67-68.

Barak, B., \& Rahtz, D. R. (1989). Cognitive age and youthfulness: Demographic and psychographic dimensions. In R. E. Kriner \& G. T. Baker (Eds.), Advances in health care research (pp. 4751). Silver Springs, MD: American Association for Advances in Health Care Research.

Barak, B., \& Schiffman, L. G. (1981). Cognitive age: A nonchronological age variable. In K. B. Monroe (Ed.), Advances in consumer research (pp. 602-606). Ann Arbor, MI: Association for Consumer Research.

Barak, B., \& Stern, B. (1986). Subjective age correlates: A research note. The Gerontologist, 26, 571-578.

Beck, B. (1996). The luxury of longer life: The world is growing older. Economist, 338(7950), 7-9.

Borra, C., \& Palma, L. (2009). Child care choices in Spain. Journal of Family and Economic Issues, 31(4), 323-338.
Brown, P. B. (1986, March 10). Last year it was yuppies-this year it's their parents. Business Week, 68-74.

Burt, S., \& Gabbot, M. (1995). The elderly consumer and non-food purchase behaviour. European Journal of Marketing, 29(2), 1543.

Carrigan, M., \& Szmigin, I. (1998). The usage and portrayal of older models in contemporary consumer advertising. Journal of Marketing Practice: Applied Marketing Science, 4(8), 231-248.

Fry, C. L. (1996). Age, aging, and culture. In R. H. Binstock \& L. K. George (Eds.), Handbook of aging and the social sciences (4th ed., pp. 117-136). San Diego, CA: Academic Press.

Goldsmith, R. E., \& Heiens, R. A. (1992). Subjective age: A test of five hypotheses. The Gerontologist, 32, 312-317.

Goodhead, V. (1991, December 9). Marketing to mature adults requires a state of being, Marketing News, 10 .

Gui, J. (2006, June 12). The young self-perceived age in the modern society. Health and Life, 9 (published in Chinese).

Henderson, K. V., Goldsmith, R. E., \& Flynn, L. R. (1995). Demographic characteristics of subjective age. The Journal of Social Psychology, 135, 447-457.

Kang, Y., \& Ridgway, N. M. (1996). The importance of consumer market interactions as a form of social support for elderly consumers. Journal of Public Policy and Marketing, 15(1), 108117.

Kastenbaum, R., Derbin, V., Sabatini, P., \& Artt, S. (1972). 'The ages of me': Toward personal and interpersonal definitions of functional aging. Aging and Human Development, 3(2), 197211.

Kim, H., \& Kim, J. (2010). Information search for retirement plans among financially distressed consumers. Journal of Family and Economic Issues, 31(1), 51-62.

Li, Y. (1998). Traditional values and healthy behavior. Guangxi University for Ethnic Minorities Journal, 20(1), 17-26 (published in Chinese).

Liu, G., \& Li, L. (1994). Contemporary Chinese values, characteristics and causes of conflict. Zaozhuang Teachers College Journal, 88-90 (published in Chinese).

Mason, S. E., \& Smith, A. (1977). Imagery in the aged. Experimental Aging Research, 3, 17-32.

Mazur, L. (1993, February 11). Golden oldies. Marketing Business, 32-33.

Miller, C. (1991, December 9). Misconception, fear stall advance into mature market. Marketing News, 11-14.

Mitchell, A. (1983). The nine American lifestyles. New York: Warner.

Mitchell, A. (1996, January). Why fray means gold. Management Today, 76-77.

Montepare, J. M., \& Lachman, M. E. (1989). You're only as old as you feel: Self-perceptions of age, fears of aging, and life satisfaction from adolescence to old age. Psychology and Aging, $4,73-78$.

Montepare, J. M., \& Zebrowitz, L. (1998). Person perception comes of age: The salience and significance of age in social judgments. Advances in Experimental Social Psychology, 30, 93-161.

Moschis, G. P. (1992). Marketing to older consumers: A handbook of information for strategy development. Westport, CT: Quorum Books.

Nunnally, J. (1978). Psychometric theory (2nd ed.). New York: McGraw-Hill.

Semon, T. T. (1995). Gerontophobia in marketing research. Marketing News, 29(1), 23-24.

Sherman, E., \& Schiffman, L. G. (1991). Applying age-gender theory from social gerontology to understand the consumer well-being of the elderly. Advances in Consumer Research, 11(1), 569-573.

Sherman, E., Schiffman, L. G., \& Dillon, W. R. (1988). Age/gender judgments and quality of life differences. In J. Shapiro Stanley \& A. H. Walle (Eds.), Marketing: A return to the broader 
dimensions (pp. 319-320). Chicago, IL: American Marketing Association.

Trappey, C., \& Lai, M. K. (1997). Differences in factors attracting consumers to Taiwan's supermarkets and traditional wet markets. Journal of Family and Economic Issues, 18(2), 211-224.

Tréguer, J. (2002). 50+ marketing: Marketing, communicating and selling to the over 50s generations. Paris: Palgrave Macmillan.

Underhill, L., \& Cadwell, F. (1983). What age do you feel: Age perception study. Journal of Consumer Marketing, 1(1), 18-27.

United Nations. (2002). Report of the Second World Assembly on ageing (A/Conf.197/9), 8-12 April, Madrid.

Weaver, P. (1996). Opportunity knocks as America ages. Nation's Business, 84(8), 30-33.

Westerhof, G. J., Barrett, A. E., \& Steverink, N. (2003). Forever young? A comparison of age identities in the United States and Germany. Research on Aging, 25(4), 366-383.

Wilkes, R. E. (1992). A structural modeling approach to the measurement and meaning of cognitive age. Journal of Consumer Research, 19(2), 292-301.

Xie, X., Xia, Y., \& Liu, X. (2007). Family income and attitudes toward older people in China: Comparison of two age cohorts. Journal of Family and Economic Issues, 28(1), 171-182.

$\mathrm{Xu}, \mathrm{Y}$. (2006, May 18). Preventing older psychological age. Chinese Medicine Report, 3 (published in Chinese).

Ying, B., \& Yao, R. (2006). Consumption patterns of Chinese elders: Evidence from a survey in Wuhan, China. Journal of Family and Economic Issues, 27(4), 702-714. (published in Chinese).

\section{Author Biographies}

Bin Ying is an Associate Professor of marketing and the Head of the Marketing Group at Zhongnan University of Economics and Law in China. Dr. Ying received his Doctoral degree in Management from Zhongnan University of Economics and Law. He was a visiting scholar in Berlin, Germany and guest researcher at Lund University, Sweden. He has published three books and about 30 journal articles in marketing and consumer behavior. His recent research areas are gray marketing, Chinese consumer behavior and Chinese local marketing.

Rui Yao Ph.D., CFP ${ }^{\circledR}$ is an Assistant Professor in the Personal Financial Planning Department at the University of Missouri. Dr. Yao received her doctoral degree from The Ohio State University. Her research interests include financial risk tolerance, savings behavior and motives, retirement preparation, debt management, and household consumption patterns. Her research received the best paper award from the CFP Board. Dr. Yao is a member of the research team on the first national survey of Chinese Consumer Finance and Investor Education. 